\title{
Jolt accentuation of headache: can this maneuver rule out acute meningitis?
}

\author{
Shirin Afhami ${ }^{1}$, Seyed Ali Dehghan Manshadi ${ }^{2}$ and Omid Rezahosseini ${ }^{2 *}$ (D)
}

\begin{abstract}
Objective: Acute meningitis is a medical emergency and its accurate diagnosis could help physicians to accelerate treatment and reduce the mortality and morbidity of patients. Jolt accentuation of headache (Jolt) is an easy clinical maneuver that can be used to diagnose meningitis, but its diagnostic accuracy is controversial. We aimed to assess the "Jolt maneuver" in diagnosis of suspected acute meningitis patients admitted to the emergency ward of ImamKhomeini Hospital Complex in Tehran, Iran.

Results: Out of 250 patients, 227 were included and 64 (28.2\%) had cerebrospinal fluid (CSF) changes compatible with meningitis. Jolt was positive in 40 of $64(62.5 \%)$ meningitis patients. Sensitivity, specificity, positive and negative likelihood ratio (+ LR and $-L R$ ) of Jolt were $62.5,88.3 \%, 5.36$ and 0.42 , respectively. These indices were also compared to nuchal rigidity, Kernig's and Brudzinski's signs. The highest + LR was for Kernig's sign (6.79) and the lowest - LR was for nuchal rigidity (0.39). CSF culture was positive in two patients (Streptococcus pneumoniae and Aspergillus sp.). We found that in adult patients with fever and acute headache, a positive Jolt maneuver has a good diagnostic accuracy for diagnosis of meningitis and indicates a need for CSF assessment, but negative results cannot exclude it.
\end{abstract}

Keywords: Meningitis, Fever, Headache, Sensitivity and specificity, Predictive value of tests

\section{Introduction}

Among the central nervous system diseases, meningitis is a potentially dangerous and debilitating disease caused by inflammation of the membranes covering the brain and spinal cord. Clinically, meningitis is defined as the presence of meningeal irritation signs (including headache, nuchal rigidity, and loss of consciousness) accompanied by fever for hours to several days. Viruses, bacteria, fungi, and even helminths can cause infection of the central nervous system. Moreover, non-infectious causes such as tumors and collagen vascular diseases can also cause central nervous system involvement and imitate signs of meningeal irritation [1].

When the signs of meningitis and cerebrospinal fluid (CSF) pleocytosis are present but they are not caused by bacterial infection, the condition is called aseptic

\footnotetext{
*Correspondence: o-rezahosseini@razi.tums.ac.ir;

omidrezahosseini@yahoo.com

${ }^{2}$ Department of Infectious and Tropical Diseases, Imam Khomeini Hospital Complex, Tehran University of Medical Sciences, Tehran, Iran Full list of author information is available at the end of the article
}

meningitis [1]. The most common cause of aseptic meningitis is viral infections ( $85-95 \%$ by enteroviruses) and these patients usually recover without treatment [2]. However, bacterial meningitis sometimes has complications even with treatment. These complications include hydrocephalus, cerebral infarction, transitional hernia, and death $[3,4]$. Among the bacterial causes, Haemophilus influenzae, Meningococcus, and Pneumococcus comprise a total of approximately $80 \%$ of cases [1]. More than 1.2 million people are diagnosed with meningitis annually and this disease is one of the 10 most frequent causes of death worldwide $[5,6]$. Therefore, timely diagnosis and treatment of this disease is of particular importance.

Among signs in a case suspicious for meningitis, nuchal rigidity, Kernig's sign, and Brudzinski's sign have been noted. In 1882, Vladimir Kernig, who was a Russian neurologist, described his famous Kernig's sign [7]. A few years later, in 1909, Josef Brudzinski, who was a pediatrician in Poland, reported that among patients with bacterial meningitis or tuberculosis symptoms, Kernig's sign had a sensitivity of $57 \%$ but the sensitivity 
of Brudzinski's sign was 96\% [8]. Since then, these signs have been used in clinical practice as cardinal signs of meningeal inflammation.

A new maneuver named Jolt accentuation of headache (Jolt) was introduced in 1991 by a group of Japanese researchers for diagnosis of acute meningitis, reporting a sensitivity of $97 \%$ and specificity of $60 \%$. Although this was a valuable finding, these results were controversial in other studies based on the strategy of patient selection and type of meningitis $[6,9,10]$.

We aimed to assess the frequency and features of Jolt maneuver in patients suspicious for acute meningitis that were admitted to the emergency ward of Imam Khomeini Hospital Complex in Tehran, Iran.

\section{Main text \\ Materials and methods Study design}

In this cross-sectional study during May 2015 to September 2016, all patients with the chief complaint of headache and fever that had started in the last 2 weeks were included if they had a diagnosis of acute meningitis. Patients with loss of consciousness or recent head and neck surgery or who did not agree to participate in the study were excluded. Demographic data, including age and sex, duration of headache, and vital signs of the patients were recorded. Results of the laboratory tests including complete blood count and differentiation $(\mathrm{CBC} /$ diff), erythrocyte sedimentation rate (ESR), C-reactive protein (CRP), blood sugar, CSF analysis, CSF and blood cultures were extracted from the patient's documents. In CSF, polymorphonuclears (PMN) were considered predominant if more than $50 \%$ of cells were neutrophils. A single physician performed all of the physical examinations before evaluating the results of the laboratory tests. The study was approved by the ethics committee of the Tehran University of Medical Sciences (No. IR.TUMS.REC. 1394.1620).

The gold standard for a diagnosis of meningitis is defined as a CSF white blood cell count (WBC) higher than 5 with or without a smear and/or culture positive cerebrospinal fluid; otherwise, it is considered negative as mentioned in previous studies $[6,10,11]$.

\section{Physical examinations}

All of the physical examinations were done in a supine and comfortable position. We did not prescribe analgesic drugs to patients before examination. In cases of nuchal rigidity, the head of the patient was flexed by the examiner toward the chest and if there was rigidity in the neck movement the test was considered positive $[4,7]$. Kernig's sign was positive if the patient had back pain or resistance during the extension of a $90^{\circ}$ flexed hip and knee [4, 7]. For Brudzinski's sign, while the legs were extended, the neck was bent towards the chest and in the event of involuntary flexion of the knee and hip, a positive test was reported [4, 7]. The Jolt maneuver was positive if the patient with extended feet had an exacerbation of headache when the head was rotated with a frequency of 2-3 times per second in the horizontal axis.

In patients with focal neurologic deficits or suspected increased intracranial pressure as well as patients with a history of seizures, a brain computed tomography scan (CT scan) was performed.

\section{Statistics and data analysis}

According to a study conducted on 14 patients, the frequency of a positive Jolt maneuver in patients with fever, headache, and neck stiffness was 63\% [11]. Considering $\mathrm{P}=0.63$ according to the Cochrane formula, $\mathrm{z}=1.96$, and $\mathrm{d}=0.063$, the required sample size was approximately 226 people and after including 10\% lost to follow-up, a sample size of 250 patients was considered. Descriptive statistics, Chi square, and independentsample t-tests (sig. 2-tailed) were used for data analysis. Sensitivity, specificity, positive and negative predictive values (PPV and NPV), and positive and negative likelihood ratios (+ LR and - LR) were calculated. $\mathrm{P} \leq 0.05$ was considered statistically significant. SPSS software (version 19, SPSS Inc., Chicago, IL, USA) was used for data analysis.

\section{Results}

A total of 250 patients were assessed and 227 patients were included in the final statistical analysis. Of these, 98 (43.2\%) were women and 129 (56.8\%) were men (Chi square test $\mathrm{P}=0.480)$. Their mean age was $46.5 \pm 17.63$ (range 18-80) years.

CSF analysis diagnosed meningitis in 64 (30 women/34 men) patients. The Jolt maneuver was positive in $40 / 64$ (62.5\%) of meningitis and 19/163 (11.7\%) of non-meningitis patients (Chi square test $\mathrm{P}<0.001$ ).

Based on the positive or negative Jolt maneuver status (J-pos and J-neg, respectively), meningitis patients were divided into two groups and clinical findings and CSF characteristics were compared (an independent t-test was applied). The results of this comparison are shown in Table 1.

When grouped by the percentage of PMN cells in the CSF, the Jolt maneuver was positive in $23 / 29$ (79.31\%) of PMN dominant patients and 17/35 (48.6\%) of lymphocyte-dominant patients (Chi square test $\mathrm{P}=0.011$ ). The frequency and percentage of evaluated signs on physical examinations according to the type of meningitis are shown in Table 2. 
Table 1 Comparison of clinical findings and CSF characteristics in meningitis patients based on Jolt maneuver status

\begin{tabular}{|c|c|c|c|c|c|c|}
\hline Variable & Jolt & Frequency & Mean \pm SD & $t$ & Df & Sig. (2-tailed)* \\
\hline \multirow[t]{2}{*}{ Age (years) } & - & 24 & $43.25 \pm 16.05$ & 0.142 & 62 & 0.887 \\
\hline & + & 40 & $42.62 \pm 17.59$ & & & \\
\hline \multirow[t]{2}{*}{ Duration of headache (days) } & - & 24 & $4.08 \pm 3.39$ & 0.749 & 60 & 0.457 \\
\hline & + & 38 & $3.55 \pm 2.18$ & & & \\
\hline \multirow[t]{2}{*}{ Body temperature } & - & 23 & $38.24 \pm 0.33$ & -1.651 & 60.63 & 0.104 \\
\hline & + & 40 & $38.43 \pm 0.54$ & & & \\
\hline \multirow[t]{2}{*}{$\mathrm{RR} / \mathrm{min}$} & - & 19 & $18.05 \pm 2.34$ & -2.220 & 52 & 0.031 \\
\hline & + & 35 & $19.51 \pm 2.29$ & & & \\
\hline \multirow[t]{2}{*}{$\mathrm{PR} / \mathrm{min}$} & - & 21 & $85.04 \pm 11.59$ & -2.639 & 58 & 0.011 \\
\hline & + & 39 & $91.97 \pm 8.53$ & & & \\
\hline \multirow[t]{2}{*}{ Sys BP (mmHg) } & - & 23 & $118.34 \pm 18.86$ & 0.188 & 61 & 0.85 \\
\hline & + & 40 & $117.57 \pm 16.12$ & & & \\
\hline \multirow[t]{2}{*}{ Dias. BP (mmHg) } & - & 23 & $74.39 \pm 9.99$ & -0.020 & 61 & 0.984 \\
\hline & + & 40 & $74.45 \pm 12.08$ & & & \\
\hline \multirow[t]{2}{*}{ WBC (cell/pl) } & - & 17 & $9184 \pm 4180$ & -2.236 & 41 & 0.031 \\
\hline & + & 26 & $11721 \pm 3244$ & & & \\
\hline \multirow[t]{2}{*}{ CRP } & - & 17 & $53.98 \pm 59.08$ & -0.193 & 37 & 0.848 \\
\hline & + & 22 & $57.16 \pm 43.74$ & & & \\
\hline \multirow[t]{2}{*}{$\mathrm{ESR}(\mathrm{mm})$} & - & 19 & $26.47 \pm 24.45$ & 0.680 & 38 & 0.501 \\
\hline & + & 21 & $32.09 \pm 27.49$ & & & \\
\hline \multirow[t]{2}{*}{ Sugar (mg/dl) CSF } & - & 24 & $53.37 \pm 18.99$ & 0.07 & 61 & 0.938 \\
\hline & + & 39 & $52.74 \pm 36.28$ & & & \\
\hline \multirow[t]{2}{*}{ Protein (mg/dl) } & - & 24 & $65.81 \pm 43.46$ & -0.79 & 61 & 0.431 \\
\hline & + & 39 & $73.90 \pm 36.54$ & & & \\
\hline \multirow[t]{2}{*}{$\mathrm{LDH}$} & - & 24 & $78.08 \pm 86.30$ & -1.38 & 55.54 & 0.171 \\
\hline & + & 37 & $125.28 \pm 177.03$ & & & \\
\hline \multirow[t]{2}{*}{ WBC (cell/pl) } & - & 24 & $276.54 \pm 471.71$ & -1.01 & 62 & 0.312 \\
\hline & + & 40 & $1338.55 \pm 5074.41$ & & & \\
\hline \multirow[t]{2}{*}{ PMN (cell/pl) } & - & 24 & $60.16 \pm 97.93$ & -2.32 & 38.17 & 0.025 \\
\hline & + & 38 & $431.68 \pm 975.97$ & & & \\
\hline
\end{tabular}

* Independent sample $t$-test

Table 2 Frequency (\%) of evaluated signs in physical examinations according to type of meningitis

\begin{tabular}{|c|c|c|c|}
\hline \multirow[t]{3}{*}{ Clinical sign } & \multicolumn{2}{|l|}{ Type of meningitis } & \multirow[t]{3}{*}{ P-value (2-sided)* } \\
\hline & PMN dominant $(\mathrm{N}=29)$ & Lymphocyte dominant $(\mathrm{N}=35)$ & \\
\hline & n (\%) & n (\%) & \\
\hline Jolt accentuation & $23(79.3)$ & $17(48.6)$ & 0.011 \\
\hline Nuchal rigidity ${ }^{a}$ & $21(75.0)$ & $28(80.0)$ & 0.635 \\
\hline Kering's sign & $14(43.8)$ & $18(56.3)$ & 0.802 \\
\hline Brudzinski's sign & $20(69.0)$ & $21(60.0)$ & 0.457 \\
\hline
\end{tabular}

* Chi square test

a Measured in 226 patients 
The sensitivity and specificity of the Jolt maneuver for the diagnosis of meningitis was 62.5 and $85.7 \%$, respectively, and the PPV was $67.7 \%$, the NPV was $85.7 \%$, and the $+\mathrm{LR}$ and $-\mathrm{LR}$ were 5.36 and 0.42 , respectively.

Among the patients with meningitis, the CSF smear was negative in all of the samples. The CSF culture was positive for S. pneumoniae and Aspergillus sp. in two samples. Blood cultures were available for 40 patients with meningitis and only one patient had a positive blood culture for S. pneumoniae. In non-meningitis patients, the blood culture was positive in 10 patients. Microorganisms such as Alcaligenes sp., Klebsiella oxytoca, S. epidermidis, and Stenotrophomonas maltophilia were considered to be due to contamination and excluded from the results.

\section{Discussion}

The Jolt maneuver in patients with meningitis has been previously reported to have a high sensitivity for the detection of acute meningitis. However, subsequent studies challenged the results of the initial study and it was found that many factors positively or negatively affected this maneuver.

In our study, at total of 227 patients were enrolled, and 64 patients $(28.2 \%)$ had meningitis; no significant difference was found between age and gender of meningitis and non-meningitis patients. The frequencies of positive Kernig's sign, Brudzinski's sign, nuchal rigidity, and the Jolt maneuver in patients with meningitis were significantly higher than among non-meningitis patients. The most common sign in examinations of patients with meningitis $(77.8 \%)$ and non-meningitis $(43.6 \%)$ was nuchal rigidity $(\mathrm{P}<0.001)$. This finding is similar to results of a study by Aminzadeh and colleagues (78.6\%) [11].

The mean of the CSF-PMN count was significantly higher in J-Pos patients $(\mathrm{P}=0.025)$ but this factor was not measured in previous studies. Hence, we cannot perform a comparison $[6,7,10-12]$.

The sensitivity and specificity of the Jolt maneuver in the diagnosis of meningitis were 62.5 and $85.7 \%$, respectively, and the PPV, NPV, + LR, and - LR were 67.7, $85.7 \%, 5.36$, and 0.42 , respectively. These findings indicate that, although a positive Jolt maneuver strongly increases the possibility of meningitis, a negative result is not able to rule out the presence of acute meningitis.

Uchihara first evaluated the Jolt maneuver in patients with meningitis in 1991 [10]. The sensitivity, specificity, + LR, and - LR of the Jolt in Uchihara's study were 97.1, $60 \%, 4.2$, and 0 , respectively. That study had a small sample size and was performed at a time when the incidence of viral meningitis was high. We performed our study with a larger sample size and a longer study period to reduce any effect of these confounding factors.
We compared our results (sensitivity, specificity, PPV and NPV, + LR and - LR) with previous studies in Table 3. Most of the previous studies, including a recent study by Sato and colleagues [13], were performed retrospectively and the examiners were all different, but we performed a prospective study and only one physician did all of the examinations to reduce bias.

As mentioned in previous studies, the sensitivity of the Jolt maneuver for detection of granulomatous meningitis, such as tuberculosis meningitis, is low [6]. Therefore, decision-making solely based on this maneuver in countries with a high TB prevalence will result in missing a significant number of TB meningitis patients. The inclusion criteria and the frequency of meningitis in each study population will affect the diagnostic sensitivity of the Jolt maneuver. This issue was noted in an article published in 2014 [9].

Jolt accentuation of headache can occur in some other intracranial pathologies. For example, in patients with migraine, the headache exacerbates during the Jolt maneuver, and also $67 \%$ of intracranial space occupying lesions have positive Jolt maneuver results [14]. The use of analgesics and carcinomatous meningitis can also affect the results of the Jolt maneuver [10, 15]. Our patients were febrile and did not have any focal neurologic deficits or known cancers and we excluded intracranial lesions by imaging. We did not prescribe analgesic drugs to our patients; however, some patients consumed oral painkillers such as acetaminophen or non-steroidal anti-inflammatory drugs (NSAIDs) before their admission.

One of our patients had bacterial and one had a fungal-positive CSF culture. Thomas and colleagues had three bacterial and six fungal positive CSF cultures [8], Whaghdhare had 3 bacterial but no fungal positives [6], and Nakao had 1 bacterial and 1 fungal positive CSF cultures [7]. Therefore, we can claim that we have good accuracy in finding cases with positive CSF cultures. However, owing to lack of samples for routine polymerase chain reaction (PCR) examination of CSF, we were unable to detect any viruses.

In conclusion, in adult patients with fever and acute headache, a positive Jolt maneuver has a good diagnostic accuracy for diagnosis of meningitis and indicates a need for assessment of the CSF, although negative Jolt results cannot exclude meningitis and the final clinical judgment rests with the physician.

\section{Limitations}

Although our prospective study with an appropriate sample size, and examination of all patients by a single physician had many strengths, we also had some limitations including the lack of routine testing for tuberculosis and 
Table 3 Sensitivity, specificity, PPV, NPV, + LR and - LR of evaluated signs in compare to previous studies

\begin{tabular}{|c|c|c|c|c|c|c|c|c|c|}
\hline Author & $\begin{array}{l}\text { Study popula- } \\
\text { tion }\end{array}$ & $\begin{array}{l}\text { Micro- } \\
\text { organism } \\
\text { (frequency) }\end{array}$ & $\begin{array}{l}\text { Sign/maneu- } \\
\text { ver }\end{array}$ & $\begin{array}{l}\text { Sensitivity \% } \\
(0.95 \mathrm{Cl})\end{array}$ & $\begin{array}{l}\text { Specifity \% } \\
(0.95 \mathrm{Cl})\end{array}$ & $\begin{array}{l}\text { PPV } \\
(0.95 \mathrm{Cl})\end{array}$ & $\begin{array}{l}\text { NPV } \\
(0.95 \mathrm{Cl})\end{array}$ & $\mathrm{LR}+$ & LR - \\
\hline Uchihara [9] ${ }^{\mathrm{a}}$ & 54 & $\begin{array}{l}\text { Viral (28) } \\
\text { Bacterial (1) } \\
\text { Tuberculosis (1) }\end{array}$ & $\begin{array}{l}\text { Jolt accentua- } \\
\text { tion }\end{array}$ & 97.1 & 60 & 80.5 & 92.3 & 4.2 & 0.0 \\
\hline \multirow[t]{4}{*}{$\begin{array}{l}\text { Thomas et al. } \\
{[8]^{\mathrm{b}}}\end{array}$} & \multirow[t]{4}{*}{297} & \multirow{4}{*}{$\begin{array}{l}\text { Viral (9) } \\
\text { Bacterial (3) } \\
\text { Fungal (6) }\end{array}$} & $\begin{array}{l}\text { Jolt accentua- } \\
\text { tion }\end{array}$ & $N R$ & $N R$ & $N R$ & $N R$ & NR & $N R$ \\
\hline & & & Nuchal rigidity & 30 & 68 & 26 & 73 & 0.94 & 1.02 \\
\hline & & & Kernig's sign & 5 & 95 & 27 & 72 & 0.97 & 1 \\
\hline & & & Brudzinski sign & 5 & 95 & 27 & 72 & 0.97 & 1 \\
\hline \multirow[t]{2}{*}{$\begin{array}{l}\text { Aminzadeh } \\
\text { et al. [11 }]^{\mathrm{a}}\end{array}$} & \multirow[t]{2}{*}{14} & \multirow[t]{2}{*}{ Undefined } & $\begin{array}{l}\text { Jolt accentua- } \\
\text { tion }\end{array}$ & 100 & 71.5 & 78 & 100 & 1 & 0 \\
\hline & & & Nuchal rigidity & 100 & 57 & 70 & 100 & 2.33 & 0 \\
\hline \multirow[t]{4}{*}{$\begin{array}{l}\text { Waghdhare } \\
\text { et al. [6] }^{\mathrm{a}}\end{array}$} & \multirow[t]{4}{*}{190} & \multirow{4}{*}{$\begin{array}{l}\text { Viral (62) } \\
\text { Bacterial (7) } \\
\text { Tuberculosis } \\
\quad(30)\end{array}$} & $\begin{array}{l}\text { Jolt accentua- } \\
\text { tion }\end{array}$ & $\begin{array}{l}6.06(2.26- \\
12.7)\end{array}$ & $98.9(94-100)$ & $N R$ & NR & 5.52 & 0.95 \\
\hline & & & Nuchal rigidity & $\begin{array}{l}39.4(29.7- \\
49.7)\end{array}$ & $\begin{array}{l}70.3(59.8- \\
79.5)\end{array}$ & $N R$ & $N R$ & 1.33 & 0.86 \\
\hline & & & Kernig's sign & $\begin{array}{l}14.1(7.95- \\
22.6)\end{array}$ & $\begin{array}{l}92.3(84.8- \\
96.9)\end{array}$ & $N R$ & $N R$ & 1.84 & 0.93 \\
\hline & & & Brudzinski sign & $11.1(5.68-19)$ & $\begin{array}{l}93.4(86.2- \\
97.5)\end{array}$ & $N R$ & $N R$ & 1.69 & 0.95 \\
\hline $\begin{array}{l}\text { Tamune et al. } \\
{[12]^{c, d}}\end{array}$ & 113 & Viral (38) & $\begin{array}{l}\text { Jolt accentua- } \\
\text { tion }\end{array}$ & $\begin{array}{l}78.9(66.0- \\
91.9)\end{array}$ & $\begin{array}{l}32.0(21.4- \\
42.6)\end{array}$ & $N R$ & $N R$ & 1.16 & 0.66 \\
\hline \multirow[t]{4}{*}{ Nakao et al. [7] ${ }^{a}$} & \multirow[t]{4}{*}{230} & \multirow{4}{*}{$\begin{array}{l}\text { Viral (1) } \\
\text { Bacterial (1) } \\
\text { Fungal (1) }\end{array}$} & $\begin{array}{l}\text { Jolt accentua- } \\
\text { tion }\end{array}$ & 21 & 82 & $N R$ & $N R$ & 1.2 & 1 \\
\hline & & & Nuchal rigidity & 13 & 80 & $N R$ & $N R$ & 0.6 & 1.1 \\
\hline & & & Kernig's sign & 2 & 97 & $N R$ & $N R$ & 0.8 & 1 \\
\hline & & & Brudzinski sign & 2 & 98 & $N R$ & $N R$ & 1 & 1 \\
\hline $\begin{array}{c}\text { Sato et al. } \\
{[13]^{\text {a,e }}}\end{array}$ & 108 & Undefined & $\begin{array}{l}\text { Jolt accentua- } \\
\text { tion }\end{array}$ & $75(61.8-84.8)$ & $35.1(24-48)$ & $N R$ & $N R$ & 1.16 & 0.71 \\
\hline \multirow[t]{4}{*}{ This study } & \multirow[t]{4}{*}{227} & \multirow[t]{4}{*}{$\begin{array}{l}\text { Bacterial (1) } \\
\text { Fungal (1) }\end{array}$} & $\begin{array}{l}\text { Jolt accentua- } \\
\text { tion }\end{array}$ & 62.5 (49.4-74) & $\begin{array}{l}88.3(82.1- \\
92.6)\end{array}$ & 67.7 (54.2-79) & $\begin{array}{l}85.7(79.2- \\
90.4)\end{array}$ & 5.36 & 0.42 \\
\hline & & & Nuchal rigidity & $\begin{array}{l}77.7(65.2- \\
86.9)\end{array}$ & $\begin{array}{l}56.4(48.4- \\
64.1)\end{array}$ & $40.8(32-50.1)$ & $\begin{array}{l}86.7(78.5- \\
92.3)\end{array}$ & 1.78 & 0.39 \\
\hline & & & Kernig's sign & $50(37.362 .6)$ & $\begin{array}{l}92.6(87.2- \\
95.9)\end{array}$ & $\begin{array}{l}72.7(56.9- \\
84.5)\end{array}$ & $82.5(76-87.5)$ & 6.79 & 0.53 \\
\hline & & & Brudzinski sign & $64(51.3-75.3)$ & $\begin{array}{l}74.2(66.6- \\
80.6)\end{array}$ & $\begin{array}{l}49.3(38.3- \\
60.5)\end{array}$ & $84(76.7-89.4)$ & 2.48 & 0.48 \\
\hline
\end{tabular}

\section{$N R$ no result}

a Meningitis was defined as WBC $>5$ cell $/ \mu \mathrm{l}$

b Meningitis was defined as WBC $>6$ cell $/ \mu \mathrm{l}$

c Meningitis was defined as WBC $>15.3$ cell $/ \mu \mathrm{l}$

d Study population was 193 patients and 113 had fever and headache without loss of consciousness

e Conscious patients

viruses on CSF and the impossibility of a final diagnosis for all patients who presented with fever and headache but did not have meningitis, and therefore, we cannot estimate the false positive and false negative rates of the Jolt maneuver.

\section{Abbreviations}

Jolt: Jolt accentuation of headache; CSF: cerebrospinal fluid; CBC: complete blood count; PMN: polymorphoneuclear; ESR: erythrocyte sedimentation rate; CRP: C-reactive protein; NSAIDs: non-steroidal anti-inflamatory drugs; PCR: polymerase chain reaction; + LR: positive likelihood ratio; - LR: negative likelihood ratio; PPV: positive predictive values; NPV: negative predictive values; J-pos: positive Jolt maneuver; J-neg: negative Jolt maneuver; CT scan: computed tomography scan. 


\section{Authors' contributions}

SA participated in planning the study, drafting the manuscript, and was the supervisor of the study. SADM participated in planning and drafting the manuscript and was the advisor of the study. OR participated in planning, data gathering, data analysis, and drafting the manuscript. All authors read and approved the final manuscript.

\section{Author details}

1 Department of Infectious Diseases, Shariati Hospital, Tehran University of Medical Sciences, Tehran, Iran. ${ }^{2}$ Department of Infectious and Tropical Diseases, Imam Khomeini Hospital Complex, Tehran University of Medical Sciences, Tehran, Iran.

\section{Acknowledgements}

We appreciate the scientific members of the Department of Infectious and Tropical Diseases of Tehran University of Medical Sciences, the central laboratory personnel of Imam Khomeini Hospital Complex, and Dr. Mohammad Hossein Tabatabaie (Resident of Radiology) because of their cooperation in this project.

\section{Competing interests}

The authors declare that they have no competing interests.

\section{Availability of data and materials}

The datasets generated and/or analysed during the current study are available from the corresponding author on reasonable request. Also, they are available in the figshare repository, https://doi.org/10.6084/m9.figshare.5234764.

\section{Consent for publication}

Not applicable.

\section{Ethics approval and consent to participate}

The research committee of the Department of Infectious and Tropical Diseases approved the proposal for the study and the ethics committee of the Tehran University of Medical Sciences, Tehran, Iran, approved its ethics (No. IR.TUMS. REC. 1394.1620). All of the patients provided written consent to use their data.

\section{Funding}

This study was self-funded by the authors.

\section{Publisher's Note}

Springer Nature remains neutral with regard to jurisdictional claims in published maps and institutional affiliations.

Received: 7 July 2017 Accepted: 26 October 2017

Published online: 30 October 2017

\section{References}

1. Bennett JE, Dolin R, Blaser MJ. Principles and practice of infectious diseases. 8th ed. Philadelphia: Elsevier/Saunders; 2015.

2. Lee BE, Davies HD. Aseptic meningitis. Curr Opin Infect Dis. 2007;20:2727. https://doi.org/10.1097/QCO.0b013e3280ad4672.

3. Hasbun R, Abrahams J, Jekel J, Quagliarello VJ. Computed tomography of the head before lumbar puncture in adults with suspected meningitis. $\mathrm{N}$ Engl J Med. 2001;345:1727-33. https://doi.org/10.1056/NEJMoa010399.

4. Brouwer MC, Tunkel AR, van de Beek D. Epidemiology, diagnosis, and antimicrobial treatment of acute bacterial meningitis. Clin Microbiol Rev. 2010:23:467-92. https://doi.org/10.1128/CMR.00070-09.

5. Scheld WM, Koedel U, Nathan B, Pfister HW. Pathophysiology of bacterial meningitis: mechanism(s) of neuronal injury. J Infect Dis. 2002;186(Suppl 2):S225-33. https://doi.org/10.1086/344939.

6. Waghdhare S, Kalantri A, Joshi R, Kalantri S. Accuracy of physical signs for detecting meningitis: a hospital-based diagnostic accuracy study. Clin Neurol Neurosurg. 2010;112:752-7. https://doi.org/10.1016/j. clineuro.2010.06.003.

7. Nakao JH, Jafri FN, Shah K, Newman DH. Jolt accentuation of headache and other clinical signs: poor predictors of meningitis in adults. Am J Emerg Med. 2014;32:24-8. https://doi.org/10.1016/j.ajem.2013.09.012.

8. Thomas KE, Hasbun R, Jekel J, Quagliarello VJ. The diagnostic accuracy of Kernig's sign, Brudzinski's sign, and nuchal rigidity in adults with suspected meningitis. Clin Infect Dis. 2002;35:46-52. https://doi. org/10.1086/340979.

9. Uchihara T. Different outcomes from different cohorts: how to validate jolt accentuation? Am J Emerg Med. 2014;32:476-7. https://doi. org/10.1016/j.ajem.2014.01.052.

10. Uchihara T, Tsukagoshi H. Jolt accentuation of headache: the most sensitive sign of CSF pleocytosis. Headache. 1991;31:167-71.

11. Aminzadeh $Z$, Roudgari A. Jolt accentuation of headache in diagnosis of acute meningitis. Iran J Clin Infect Dis. 2010;5:106-9.

12. Tamune H, Takeya H, Suzuki W, Tagashira Y, Kuki T, Nakamura M. Absence of jolt accentuation of headache cannot accurately rule out meningitis in adults. Am J Emerg Med. 2013;31:1601-4. https://doi.org/10.1016/j. ajem.2013.08.028.

13. Sato R, Kuriyama A, Luthe SK. Can we rule out meningitis from negative jolt accentuation? A Retrospective Cohort Study. Headache. 2017;57:58692. https://doi.org/10.1111/head.13022.

14. Blau JN. How to take a history of head or facial pain. Br Med J. 1982;285:1249-51.

15. Tamune H, Kuki T. High pretest probability of meningitis requires lumbar puncture regardless of the finding of jolt accentuation of headache. Am J Emerg Med. 2014;32:477-8. https://doi.org/10.1016/j.ajem.2014.01.047.

\section{Submit your next manuscript to BioMed Central and we will help you at every step:}

- We accept pre-submission inquiries

- Our selector tool helps you to find the most relevant journal

- We provide round the clock customer support

- Convenient online submission

- Thorough peer review

- Inclusion in PubMed and all major indexing services

- Maximum visibility for your research

Submit your manuscript at www.biomedcentral.com/submit
Ciomed Central 